ISSN: 2576-2141

\title{
Collaborative Autoethnography as a Pathway for Teacher Learning
}

\author{
Nugrahenny (Henny) T. Zacharias ${ }^{1}$ \\ Penn State Abington \\ Galina Shleykina \\ Southeastern Oklahoma State University
}

\begin{abstract}
In this article, we present lessons learned through the use of Collaborative Autoethnography (CA), a qualitative research method where two international faculty members use their stories constructed from the year-long participation in a Faculty Learning Community (FLC) at a midwestern university in the US. The FLC aimed at providing a safe shared space where international faculty and graduate students discussed the struggles, challenges, and joys of their 'international-ness'. The autoethnographic reflection illustrates how participation in a FLC has helped them to mediate their initial worries and dilemma of being international faculty (Galina) and reconceptualize teaching (Henny) in a productive way. Additionally, the study demonstrates how reflecting on one's experience through autoethnography helps them to draw tangible lessons connecting their participation in FLC to their individual teaching contexts and personal struggle in performing a viable teacher identity. The article ends with pedagogical implications on how future FLCs can be better structured to meet the needs of international faculty.
\end{abstract}

KEYWORDS: Collaborative Autoethnography, Faculty Learning Community, Teacher Learning, Teacher Professional Development and Learning.

Autoethnography is a research method where the researchers use data from their own situated life stories to "gain an understanding of society through the unique lens of the self" (Chang et al., 2012, p. 18). Different from other qualitative methods, in autoethnography, the researcher's self, who in many positivist researchers is 'hidden,' is foregrounded as 'important source of knowledge ... and source of insight into cultural experience" (Ellis \& Adams, 2014, p. 254). Leading scholars in autoethnography such as Ellis and Bochner (2000) claim that autoethnography is not just about retelling stories; rather, it represents "carefully organized research designs, process-oriented questions, and the intentional engagement of the self" (Blalock \& Akehi, 2018, p. 93). Reflexivity is a key to autoethnographic research since it provides access into researchers' "innermost thoughts" (p. 18), vulnerabilities, and struggles that most often "lie beyond the research of other research methods" (Chang, 2016, p. 18).

Collaborative autoethnography (or CA for short) emerges from autoethnography analysis where a duo or team of researchers works together and self-interrogate their experiences in a collective and cooperative way (Chang, 2016). Blalock and Akehi (2018) put forward two entry points where CA may begin. First, it may begin to process and understand a traumatic and/or racial event. The second point is to understand a diverse way of making meaning out of a similar experience. For us, it was our shared participation in a Faculty

\footnotetext{
${ }^{1}$ Corresponding Author E-mail: ntz5022@psu.edu
} 
Learning Community (FLC) focusing on our international status that invited us to explore lessons learned through autoethnography. The research question guiding our study is: How does autoethnography mediate two international faculty's learning through their participation in a year-long FLC?

\section{Theoretical Framework}

\section{Teacher Professional Development and Learning (TPDL)}

Teacher professional development and learning (TPDL) is one of the keys to improve the quality of student learning, the ultimate goal of any education. While all teachers can benefit from TPDL, Farrell (2013) asserted that TPDL is particularly important for experienced teachers because the way experienced teachers approach teaching is different from novice teachers. Since they have limited practical classroom experience, novice teachers tend to teach from theories and then, look at how these theories can be transformed into their respective classrooms. While novice teachers generally work from theory to practice, experienced teachers draw their teaching from years of practical classroom experience echoing Dewey's (1916) value of experience: "An ounce of experience is better than a ton of theory simply because it is only in experience that any theory has vital and veritable significance" (p. 169). While we generally agree with Dewey, it is important to highlight that not all experiences have "vital and veritable significance" if there is no systematic attempt to step back and reflect on these experiences which can be afforded by TPDL programs.

TPDL programs have different focuses and forms. In higher education, a common form of TPDL is Faculty Learning Communities (FLCs). While many TPDL programs focus on exposing teachers to the latest theories and/or teaching approaches (Poehner, 2011) without considering teacher individual teaching circumstances, FLC creates an academic learning community where teachers' individual and isolated teaching circumstances are placed at the forefront of teachers' learning and reflection. In FLCs, faculty meet for an extended period of time to discuss and share ideas concerning pedagogy with "the goal of enhancing their students' classroom learning experience" (Flores \& Olivas, 2017, p. 107). Due to the sustaining manner of FLC, Beach and Cox (2009) assert that participating in an FLC often leads to innovative and attitudinal change that faculty might not achieve individually or by attending a one-time workshop/program.

While the effects of FLCs are well-documented from FLC facilitators' perspectives (Flores \& Olivas, 2017; Ortquist-Ahrens \& Torosyan, 2009; Rubadeau \& Mumford, 2018), to date there are somewhat limited studies addressing FLC members' personal and professional experiences when participating in such a community. Since TPDL can be "complicated, prolonged, highly situated, and deeply personal process" (Johnson \& Golombek, 2011, p. xi), there is a need to make it public how FLCs contribute to the professional development and learning of their participants. This information can better inform future FLC facilitators of possibilities and challenges these members face in their respective teaching contexts.

\section{Faculty Learning Communities as a Media for TPDL}

Since its establishment in 1979, FLC has undergone different definitions (Cox, 2019) which vary with regard to length of time from six months to a year-long, recruitment of members (e. g. cross-disciplinary, multidisciplinary), and number of participants (Cox, 2004). Despite these differences, the definitions agree that FLC aims to enhance "teaching and learning and includes the goals of building community, engaging in scholarly practice, and developing the scholarship of teaching and learning" (Cox, 2019, p. 76). In short, FLCs provide a safe and collaborative academic space for individual faculty to discuss and share their individual 
pedagogical concerns that eventually improve the academic culture in the societal and institutional levels.

Studies have shown that FLCs, among other achievements, are highly successful in addressing TPDL. Beach and Cox (2009) have demonstrated how FLC members of six universities applied new pedagogical approaches such as active, student-centered and collaborative learning, and observed changes in teachers' attitudes which improved students' learning and educational outcomes. O'Meara (2005) documented the improved teaching confidence and faculty's willingness to experiment with new teaching techniques such as active learning and assessment tools in the field of STEM. Daly (2011) discussed how FLCs foster faculty learning as individuals and as a community and enhance instructors' motivation and competence.

Additionally, FLCs improve faculty scholarly productivity and sociability (Searby et al., 2009) and stimulate the development of teacher-scholar model (Sweet et al., 2019). They encourage the development of new original pedagogical innovations, for example, combining composition and math (Day \& Frost, 2009); critically address the issues of diversity and multiculturalism in creating and using culturally responsive teaching practices such as establishing welcoming classroom climate, leading topical conversations, and providing an open space for discussions (Flores \& Olivas, 2017); and enhance individual as well as collective learning of participating instructors (Carter et al., 2010). Such advances of FLC have an overall positive effect on teaching effectiveness as evidenced in course evaluations (Vandermolen et al., 2018), on the professional growth of educators in reflective and dialogic practices (Dees et al., 2009), and on the professional needs of the faculty in general (Cox, 2002).

\section{Methodology}

\section{Research Context}

Henny and Galina participated in a year-long FLC held at a midwestern university in the US and facilitated by two senior international faculty. The FLC "Enriching Teaching Experiences of International Faculty, international Teaching Assistants (ITAs), and Graduate Students" was designed specifically to address the unique needs and challenges faced by international faculty members and graduate students. The group met a total of ten times and each meeting lasted for two hours. Most of the meetings centered on discussing peer-reviewed journal articles focusing on how international faculty and/or nonnative English-speaking teachers negotiate their international-ness and/or non-nativeness in the US academic context. On several occasions, guest speakers who were also international faculty members at the university were invited to share teaching experiences and pedagogical strategies on how to increase teaching effectiveness. Guest speakers from the university administration and from the student body also talked to the FLC members about their experiences and expectations of international instructors. Other activities included open discussions, collaborative presentations, peer reviews of teaching statements, and role-plays on the topics pertaining to international instructors' teaching.

\section{Participants/Researchers}

What follows is a brief description of us as researchers and participants.

Henny joined the FLC during her fourth year as a Visiting Assistant Professor (VAP) at the university where she taught three classes of first-year composition to international students. For her, teaching which is supposed to be "an ongoing process of change" (Buchanan et al., 2018, p. 67) has turned into teaching a familiar endeavor because of the large number of hours spent on teaching and grading. After teaching for approximately three years, she felt the need 
to subject the familiar for a change. And participating in a year-long FLC where faculty can learn from one another was an effective media for such a change.

Galina participated in FLC during her third year at Miami - also as a VAP - where she was teaching international composition, TESOL (Teaching English as a Second Language), and linguistic courses. Her status as an international instructor together with her area of academic expertise - TESOL and linguistics, made her interested in joining the FLC. Since the FLC focused on international faculty, she was curious if the FLC could help her to conceptualize the international-ness in a more positive way. She was well aware that one crucial job of a language teacher is to be a role model for the learners (McGrath, 2013; Medgyes, 2001), but at the same time was concerned if her international status and nonnative speech would be a hindrance to achieve such a role.

\section{Data Collection and Analysis}

According to Chang (2016), personal memories are the building blocks of autoethnography. The main data in our ethnography is personal memories of experiences, conversations with others and self-reflections. In this study, we adopt Ngunjiri et al. (2010) "concurrent model" (p. 6). Following this model, each of us selected a topic for data collection and independently wrote the autoethnographic narrative drawn from FLC participation. We began our collaboration by deciding on the general direction of the research and formed a tentative research question "How does autoethnography mediate two international faculty's learning through their participation in a year-long FLC?" for the beginning stage of data collection. In the next step, we individually wrote our experiences. This isolated storying of our personal experience allowed us to reflect on our autoethnographic data without the interference of one another. We, then, met regularly to discuss our individual stories. During these sessions, we offered each other's feedback and took notes which we added to our pool of data. In the final stage, we gathered to share, review, and interrogate each other's stories to extract the final interpretations and conclusions of our individual stories.

\section{Implementation of Autoethnographic Reflection}

In what follows, the authors share their reflections on the lessons learned using autoethnography as a tool within their roles and responsibilities as a Visiting Assistant Professor.

\section{Henny's Story: Teaching as a Relationship}

One benefit of FLC cited by many teachers in Buchanan et al.'s study (2018) is the opportunity to focus on a specific aspect of teaching in a collaborative manner. The way I saw knowledge transmission slowly shifted when 'student-centered learning' became a reoccurring topic in FLC meetings. I quickly learned that I came from a teaching context described by Western academics as mostly teacher-centered. Different from the US, in Indonesia, my home country, student evaluations were not an integral part of teaching. Even though they were occasionally administered, they did not have any direct bearing to teacher promotion. In 15 years of teaching in Indonesia, I have never heard any teachers who have been denied promotion due to poor student evaluations.

Since student evaluation was not an integral part of teaching as in the US, I did not spend time seriously considering the comments students wrote in the evaluation. One comment that students consistently wrote in my evaluation when I was teaching in Indonesia as well as in the US were "I think the class needs to be more fun!" and "Perhaps, play games once in a while." When I was reading them in Indonesia, I easily pushed them aside for the simple reason 
because at the time, I viewed learning as a serious endeavor. My 'belief' was also reinforced by many disciplinary content courses I was assigned to teach such as "Research Methods", "Introduction to Linguistics" and "Discourse Analysis." Since courses in Indonesia was often co-taught with other teachers and was mostly textbook-centered, it is important that these courses were taught at the same pace and way. Individual innovation in each course was difficult, if not impossible. All teachers needed to cover the same materials since tests and quizzes were given on the same day and time. Therefore, when I received student comments to make lessons "more fun", I saw this as a distraction to the 'serious' learning outcome achieved mostly through 'serious' means such as tests and quizzes.

When immigrating to the US, I learned the significance of student evaluations in teaching effectiveness. And this has certainly changed the way I structure and value my teaching. One useful activity in the FLC meeting was when we had a chance to listen to guest speakers who were also international faculty in the university. From them, I learned that 'how to teach' is as important, if not more important, than 'what to teach'. It is this awareness that shifted the way I see teaching and students. I now see teaching as a relationship. The way I see teaching as a relationship echoes Palmer's (1998) idea of connectedness where they can "weave a complex web of connections among themselves, their subjects, and their students" (p. 11). Seeing 'teaching as a relationship' (or TR, for short) highlights the significance of each component contributing to the relationship: the teacher, students, and communication. If an individual-based view of teaching, such as teacher- or student-centered, gives a focus on only one component of teaching, TR focuses on the functionality of all the components and most importantly, it highlights the dialogical and effective relationship between the two.

Seeing TR includes demonstrating how students can be collaborators for my pedagogy. In addition to administering mid-semester reflection and seeking student feedback of class activities, I also regularly have a class activity where writing samples from former students become learning materials. Students work in groups and grade them with the available rubric. Class discussion following such activity shows how the activity seems to be fruitful not only for the students but especially for me-the teacher. Although we mostly agreed on a sample essay which received $\mathrm{F}$ and $\mathrm{A}$ letter grades, $\mathrm{B}$ and $\mathrm{C}$ essays were less straightforward. There were several occasions where the majority of students assigned a B grade on an essay that I have graded as an A. This discrepancy has become a futile space where I can learn the different ways 'good writing' is defined in students' previous educational settings. I, then, was able to utilize this information to align my explanation to what students have already known. I found that this activity was meaningful when several students did not hesitate to ask when I would post the sample essay several weeks before a major assignment was due. Many students even wrote in the student evaluations that discussing sample essays was one class activity contributing to their writing development.

In addition to using student writing as sample essays, another way to make students as teaching collaborators is by demonstrating how students can complement teacher instruction. For example, the announcement below was posted on Canvas (the learning management system we used at the university) at the end of the Fall 2019 semester:

I have posted an example of two paragraphs that use two or more class activities as a source of change.

Li of ENGL109CB brought to my attention that many of the sample paragraphs we used for practice on Wednesday, do not have two activities as sources of change. So, I have posted two examples that use TWO or more 'sources of change' to Module $>$ Week 15. So, thank you Li for critically evaluate the sample paragraph $\odot$. See you, All, tomorrow! 
The announcement was written based on a student email ( $\mathrm{Li}$, a pseudonym) inquiring why the sample paragraphs that I gave for one of the major assignments were actually different from the writing students expected to produce. When I wrote the announcement, I initially did not intend to write Li's name. I, then, realized the need to write the reason for how I came to such an awareness. My aim is two-fold. First, is to show students that a teacher is not 'perfect,' and therefore, they should not be hesitant in pinpointing inadequacy in my teaching. And second, students can better assist my teaching by pinpointing how teaching materials can be improved to better meet their academic needs. In short, TR helps me to acknowledge and demonstrate students' role to improve my teaching and eventually, their learning.

Flores and Olivas (2017) noted that FLCs aim to provide a space for faculty learning with the end goal of enhancing students' learning. My autoethnography generally depicts how participating in a FLC helps me to find a way to reconceptualize my teaching to fit my teaching context. If Vescio et al.'s study (2008) see participation in a FLC helps teachers to make their teaching practices be more student-centered, I see teaching not as an individualized-based endeavor but as a relationship between individuals, in this case, students and the teacher.

\section{Galina's Story: Teaching as Role-Modelling}

My story with FLC began during my third year as a VAP teaching composition, ESL (English as a Second Language), and linguistic courses. My status as an international instructor, a non-native English speaker together with my area of academic expertise - TESOL and linguistics, made me interested in this FLC. Since the FLC focused on international faculty, I was hopeful that the FLC would help me to re-envision my international-ness and support it through communication with peers.

When I was entering American academia as a graduate student and as an international teaching assistant (ITA), the non-nativeness of speech was the biggest fear - "Will American students understand me? What if they won't? What should I do then?" I had heard 'horror' stories from my peer ITAs about students' complaints such as "my instructor cannot speak good English, "my instructor speaks in broken English", or "has a very heavy accent" emphasizing poor learning experience. These stories have never bothered me until one critical incident happened. At the end of my third year as an ITA, I read a critical comment from one of the international students in my ESL Oral Skills class in the anonymous semester-end course evaluations. In the answer to the question "How would you evaluate the course and your learning experience?", the student negatively evaluated the course because it was taught by a "foreign" instructor with a "foreign" accent. The student further explained that "non-native speakers of English" should not teach English courses since their language skills and pronunciation specifically are not "perfect." After I have read that comment, I have started reflecting on the semester and class activities and was not able to remember any negativity from the students. Nor was I able to recall any significant misunderstandings or miscommunications with the students. Quite the contrary - all students in the class seemed positive about the class activities and my teaching and it seemed to me that we were working together very well. So, the covert and unexpected criticism on the course evaluation shocked me. It struck me for several reasons. First, the comment did not explain what "perfect" pronunciation, "native" and "non-native" speech mean and what the student expected from the instructor in terms of pronunciation or accent. The student's comment suggested that non-native speakers of English could not make good teachers because they have foreign accents. In this, the comment revealed unawareness of the global English use and showed preference for an ideal (and unrealistic) native speaker or someone without a foreign accent. Another reason of my shock was that the comment came from an international student, and in my experience, international students in general demonstrate solidarity towards other international peers. But when it comes to the nonnative English speaker teachers, the students are not tolerant in regards to accent, as the 
comment demonstrated. Lastly, and more importantly, the comment shocked me because it was discouraging to me personally - as to a person speaking with a foreign accent - and eventually contributed to my initial insecurity and worries whether I can be a successful role model for my students, whether I can encourage and inspire them.

To add to this incident, I found evidence in the academic research literature that international instructors are viewed as less credible, less clear and less intelligible, are often considered "poor teachers" because of their foreignness (Rubin, 1992, p. 394), accentedness of speech, and negative accent stereotyping (Lippi-Green, 1997; Subtirelu, 2015). And even though studies of international faculty have significantly increased in the recent years in academia in the US (Altbach \& Yudkevich, 2017) and the general awareness has grown, linguistic and professional competence of an instructor who speaks "English with an accent" (Lippi-Green, 1997) is still commonly questioned.

In this context of inner insecurity of representing a role-model, I was pondering upon the questions of my professional legitimacy and the influence of my accent and foreignness on the students' learning and my teaching. I was looking for a place to mediate my fears and insecurities and entered the FLC with the hopes to get support and find an answer to the question if I could be seen as a successful role-model for the students and if my non-nativeness is a hindrance in it. The answer - unsurprisingly - was the prevalence and complexity of the issue. At our FLC meetings, I have heard many stories from peer instructors about non-nativeness of speech and foreign accents as a challenge or a source of instructor's anxiety in the classroom (Resources for International Faculty and Teaching Assistants, n. d.). Moreover, as we discussed on the FLC meetings, the concept of 'non-nativeness' combines views of domestic and international students, perceptions and conventions in particular disciplines, racial and ethnic stereotypes, and attitudes towards the English language varieties in general. Although these meeting often did not give direct and clear answers, they provided a safe space where we international instructors - could raise our voices and could be heard; they provoked open-ended discussions and conversations which helped address and overcome fears and insecurities.

In the TESOL and applied linguistics, the issue of "native speakerism" in general and in accent specifically is well discussed (see, for example, Braine, 2010; Dziubalska-Kołaczyk $\&$ Przedlacka, 2008). The consensus is the departure from the native speaker model and not necessarily focusing and adhering to these norms in teaching (Houghton et al., 2018; McKay, 2002). Given the widespread of negative stereotypes which are often expressed in students' evaluations or negative comments, as mentioned above, the fear or discomfort of the accent that many international instructors have, and lack of awareness and misconceptions about accents, I felt the need to share the advances of the TESOL and applied linguistics studies with my FLC peer members.

An activity I suggested to hold during our FLC meetings was a simulation - a learning task where participants work as a group and play particular roles. As a result of conversations and discussions, they need to come to a consensus in solving a problem or making a decision. The chosen simulation was "The ITA PROBLEM" (Halleck, 2008) which evolves around the debate of ITAs teaching in American universities. Such an activity provided new insights on the issue and a new approach towards challenging conversations and at times uncomfortable topics. More importantly, the open and live discussion during the simulation eliminated my initial discomfort to reveal the non-native accent. Such discomfort and fear quickly disappeared in conversations with other ITAs and international faculty at FLC meetings and through reading relevant research (Reis, 2012). Even more importantly, my reflexivity on my experience in working with international students became a crucial component of my learning (Greene \& Park, 2021). Upon reflection stimulated by the FLC meetings, I have realized that it is important to talk about our 'non-nativeness' in accent. I included short discussions about the role of English as an international global language with examples of accented speech - in speaking and writing, introduced code-meshing as a rhetorical tool, added an assignment - weekly reflective 
journal on writer's identities and expectations, and encouraged open conversations about writing and speaking with an accent. In addition, I shared my own writing struggle and anxiety, for example in choosing the right words, thinking about the effect they have on my readers, working on clarity and conciseness, and so on. That way - through such activities and more importantly, personal examples, - the students can see my 'non-nativeness' in the English classroom as a valuable resource in sharing first-hand experiences of learning English, explaining English grammar rules, rhetorical tools and learning strategies. I came to an understanding that my experiences and stories can have an impact on shaping my students' skills and attitudes. I started to see myself as a role-model for successful learning of a new language. The students' reaction to my experiences was not long in coming and was encouraging for me as a teacher. The students asked for advice and shared their stories. Emails or questions from students such as the one below are not uncommon in my practice:

\section{Professor Galina! Do you have any recommended books or websites to learn English faster? I heard you from Russia. The question I most want to ask is how did you learn your English well and how did you learn to speak so frequently to native people?}

Such role-modelling helps establish rapport with students positive attitude and atmosphere in the classroom. Additionally, international students feel solidarity and compassion of an international instructor who understands challenges of acculturation and developing a new self in a new culture in a new language, anticipate difficulties, and is empathetic to language learners (Medgyes, 2001). The comments that I have received in students' evaluations reflect such a view: "Being an international, she is good with international students", "This is a very considerate teacher, as a foreigner, she can understand the problems of international students", "very clear and easy to understand."

The lessons that I have learnt from my teaching experience and FLC go in line with my TPDL goals: they include conceptualizing of my teaching as role-modelling and my international status and perspective as a benefit and privilege rather than deficit and limitation (Etchells et al., 2017, Hutchison, 2016; Park, 2012; Song \& Del Castillo, 2015).With the help from colleagues and peers in a supportive collegial environment, I can share my expertise and experience in learning to teach and introduce broad perspectives and linguistic and communicative diversity and, broadly, the "pedagogy of cultural wealth" (Yep, 2014, p. 88).

\section{Conclusions}

In our article, we demonstrated how CA mediated our learning and supported our professional development through participation in a year-long FLC. In addition, our stories support earlier findings on the benefits of FLCs to TPDL of international faculty (Buchanan et al., 2018; Dorbney et al., 2010; Flores \& Olivas, 2017). Through autoethnography, Henny was able to find ways to center her teaching on the student learning and perceive teaching more as having a relationship with students where she views students as pedagogical collaborators. Galina was able to position and strengthen her teaching as role-modelling for international students and to see the benefits of non-nativeness in the classroom. Together, these stories show how sharing and collaborating with like-minded individuals (Cox \& McDonald, 2017) can lead to professional transformation in teaching.

The study has a number of implications. First, it supports the need to hold FLCs focusing on international faculty. While a theme-based FLC has begun since 1980 (Dees et al., 2009), to the best of our knowledge, this is the first reported FLC focusing on international and/or nonnative faculty in the US. The FLC that we both participated in has helped us to address teaching and professional dilemmas that we had as well as empower us to find productive ways to 
address these dilemmas in our own teaching contexts. Second, our findings suggest the need to include many different activities to mediate members' reflection. The discussions during FLC meetings gravitated around the following activities: reading research articles focusing on professional issues of being a nonnative English teacher and faculty of color, inviting guest speakers, collaborative presentations, a role-play simulation addressing ITAs' teaching of American undergraduate students, and a peer review process on our individual reflections and teaching philosophy statements. Despite the variety of tasks all members engaged in, our individual stories illustrated that not all activities led to meaningful reflection. It is only through CA that we are able to find connection between FLC and our individual classroom and teaching context. Future FLCs could consider implementing autoethnographic-based activities to mediate members' reflection.

The purpose of autoethnography is not to provide generalizability of finding as in quantitative research methods but to provide "rich transferable implications for other higher education teaching contexts" (Rubadeau \& Mumford, 2018, p. 58). Additional autoethnographic studies focusing on members' experiences are needed so the ways FLCs contribute to members' TPDL can be more evident. Reflecting members' experiences autoethnographically also provide thick description allowing FLC facilitators to better accommodate future needs of the members.

\section{References}

Altbach, P. G., \& Yudkevich, M. (2017). Twenty-first century mobility: The role of international faculty. International Higher Education, 90, 8-10.

Beach, A., \& Cox, M. (2009). The impact of faculty learning communities on teaching and learning. Learning Communities Journal, 1(1), 7-27.

Blalock, A. E. \& Akehi, M. (2018) Collaborative autoethnography as a pathway for transformative learning. Journal of Transformative Education, 16(2), 89-107.

Braine, G. (2010). Nonnative speaker English teachers: Research, pedagogy, and professional growth. Routledge.

Buchanan, L. B., Moody, A., Fox, K. R., \& Hargrove, T. Y. (2018). Professional learning communities as teacher educator professional development: Articulating the impact on pedagogy and student learning. Learning Communities Journal, 10, 67-85.

Carter, T. J., Nugent, J. S., Reardon, R. M., Rhodes, J. A., \& Smith, F. G. (2010). Self-directed learning in a faculty learning community: The FLC as "organizing circumstance." Learning Communities Journal, 2(1), 27-48.

Chang, H. (2016). Individual and collaborative autoethnography as method. In S. H. Jones, T. E. Adams, \& C. Ellis (Eds.), Handbook of autoethnography (pp. 107-122). Routledge.

Chang, H., Ngunjiri, F. W., \& Hernandez, K. C. (2012). Collaborative autoethnography. Left Coast Press.

Cox, M. D. (2002). The role of community in learning: Making connections for your classroom and campus, your students and colleagues. In G. S. Wheeler (Ed.), Teaching and learning in college: A resource for educators (pp. 1-38). Info-Tec.

Cox, M. D. (2004). Introduction to faculty learning communities. New Directions for Teaching \& Learning, 97, 5-23.

Cox, M. D. (2019). FLC definition and recommendations: A yearlong vs. a one-semester FLC and an honors program example. Learning Communities Journal, 11, 75-106.

Cox, M. D., \& McDonald, J. (2017). Faculty learning communities and communities of practice: Dreamers, schemers, and seamers. In J. McDonald \& A. Cater-Steel (Eds.), Communities of practice (pp. 47-72). Springer. 
Daly, C. J. (2011). Faculty learning communities: Addressing the professional development needs of faculty and the learning needs of students. Currents in Teaching \& Learning, 4(1), 3-16.

Day, K., \& Frost, J. (2009). Sharing the WARMth: Writing and reading mathematics in a learning community. Learning Communities Journal, 1(1), 91-111.

Dees, D. M., Zavota, G., Emens, S., Harper, M., Kan, K. H., Niesz, T., Tu, T. -H., Devine, M. A., \& Hovhannisyan, G. (2009). Shifting professional identities: Reflections on a faculty learning community experience. Learning Communities Journal, 1(2), 49-73.

Dewey, J. (1916). Democracy and Education. Macmillan.

Drobney, K., Cardone, T., Hartsell-Gundy, A., Platt Jendrek, M., Resnis, E., \& Stonecipher, B. (2010). Narratives of personal transformation in engaged learning. Learning Communities Journal, 2(2), 27-51.

Dziubalska-Kołaczyk, K., \& Przedlacka, J. (Eds.) (2008). English pronunciation models: A changing scene. Peter Lang.

Ellis, C., \& Adams, T. E. (2014). The purposes, practices, and principles of autoethnographic research. In P. Leavy (Ed.), The Oxford handbook of qualitative research (pp. 254-276). Oxford University Press.

Ellis, C., \& Bochner, A. P. (2000). Autoethnography, personal narrative, reflexivity. In N. Denzin \& Y. Lincoln (Eds.), Handbook of qualitative research (2nd ed., pp. 733-767). Sage.

Etchells, M. J., Deuermeyer, E., Liles, V. M., Meister, S. M., Suarez, M. I., \& Chalklen, W. L. (2017). White Male Privilege: An Intersectional Deconstruction. Journal of Ethnic and Cultural Studies, 4(2), 13.

Farrell, T. S. C. (2013). Reflective practice in ESL teacher development groups: From practices to principles. Palgrave Macmillan.

Flores, I. M., \& Olivas, A. P. (2017). Bringing awareness of cultural competence to a university campus: A faculty learning community's journey. Learning Communities Journal, 9, 107-131.

Greene, M. V. \& Park, G. (2021). Promoting reflexivity during the COVID-19 pandemic. American Journal of Qualitative Research, 5(1), 23-29.

Halleck, G. B. (2008). The ITA problem: A ready-to-use simulation. Simulation \& Gaming, 39(1), 137-146.

Houghton, S. A., Rivers, D. J., \& Hashimoto, K. (2018). Beyond native-speakerism: Current explorations and future visions. Routledge.

Hutchison, C. B. (Ed.). (2016). Experiences of immigrant professors. Routledge.

Johnson, K. E. \& Golombek, P. R. (2011). (Eds.) Language teacher education: A sociocultural perspective on professional development. Routledge.

Lippi-Green, R. (1997). English with an accent: Language, ideology, and discrimination in the United States. Routledge.

McGrath, I. (2013). Teaching materials and the roles of ESL/EFL teachers: Practice and theory. Bloomsbury.

McKay, S. L. (2002). Teaching English as an International Language. Oxford University Press.

Medgyes, P. (2001). When the teacher is a non-native speaker. In M. Celce-Murcia (Ed.), Teaching English as a second or foreign language (3rd ed., pp. 415-428). Heinle \& Heinle.

Ngunjiri, F. W., Hernandez, K. C., \& Chang, H. (2010). Living autoethnography: Connecting life and research [Editorial]. Journal of Research Practice, 6(1), Article E1. http://jrp.icaap.org/index.php/jrp/article/view/241/186

O'Meara, K. (2005). The courage to be experimental: How one faculty learning community influenced faculty teaching careers, understanding of how students learn, and assessment. Journal of Faculty Development, 20(3), 153-160. 
Ortquist-Ahrens, L., \& Torosyan, R. (2009). The role of the facilitator in faculty learning communities: Paving the way for growth, productivity, and collegiality. Learning Communities Journal, 1(1), 29-62.

Palmer, P. J. (1998). The Courage to Teach: Exploring the Inner Landscape of a Teacher's Life. Jossey-Bass.

Park, G. (2012). "I am never afraid of being recognized as an NNES": One teacher's journey in claiming and embracing her nonnative-speaker identity. TESOL Quarterly, 46(1), 127151.

Poehner, P. (2011). In K. E. Johnson \& P. R. Golombek, (Eds.), Language teacher education: A sociocultural perspective on professional development (pp. 189-203). Routledge.

Reis, D. S. (2012). "Being underdog": Supporting nonnative English-speaking teachers (NNESTs) in claiming and asserting professional legitimacy. Journal on Excellence in College Teaching, 23(3), 33-58.

Resources for International Faculty and Teaching Assistants. FLC member reflections. (n. d.). Retrieved from https://miamioh.edu/cte/resources/intl-resource/index.html

Rubadeau, K., \& Mumford, M. J. (2018). International non-tenure track faculty in a faculty learning community in Korea: Opportunity to perform. Learning Communities Journal, $10,41-65$.

Rubin, D. (1992). Nonlanguage factors affecting undergraduates' judgments of nonnative English-Speaking teaching assistants. Research in Higher Education, 33 (4), 511-531.

Searby, L. J., Ivankova, N. V., \& Shores, M. L. (2009). Capable, contributing, and connected: New professors find support through a peer learning community. Learning Communities Journal, 1(2), 97-119.

Song, K. H., \& Del Castillo, A. G. (2015). NESTs' professional identity in the linguistically and culturally diverse classrooms. International Journal of Educational Psychology, 4(1), 54-83.

Subtirelu, N. C. (2015). "She does have an accent but...": Race and language ideology in students' evaluations of mathematics instructors on RateMyProfessors.com. Language in Society, 44, $35-62$.

Sweet, C., O'Brien, S., Blythe, H., \& Carpenter, R. (2019). A new goal for professional development: A case study of how a professional learning community produced transformative faculty learning. Learning Communities Journal, 11, 55-73.

Vandermolen, R. M., Meyer-Looze, C. L., Smith, C. S., \& Richards, S. L. (2018). Increasing teacher effectiveness through faculty learning communities. Learning Communities Journal, 10, 7-26.

Vescio, V., Ross, D., \& Adams, A. (2008). A review of research on the impact of professional learning communities on teaching practice and student learning. Teaching \& Teacher Education, 24, 80-91.

Yep, G. A. (2014). Talking back: Shifting the discourse of deficit to a pedagogy of cultural wealth of international instructors in US classrooms. New Directions of Teaching \& Learning, 138, 83-91. 


\section{Notes on Contributors}

Nugrahenny T. Zacharias (Henny) is an Assistant Teaching Professor at Penn State Abington. Her research interests lie in the interface between multimodality, second language writing, and autoethnography. Her writing has been published in TESOL Journal, RELC Journal, Journal of Asian Pacific Communication, and Current Issues in Language Planning.

Galina Shleykina is an Assistant Professor of English at Southeastern Oklahoma State University. She has taught and researched Linguistics and English as a Second and a Foreign Language in Russia and the US. Her research interests include interlanguage pragmatics, pragmatic competence and performance, teaching of speech acts, and simulation-based language teaching.

Manuscript received April 13, 2021 Final revision received June 16, 2021 